\title{
Preparation of Silver Nanoparticle and Its Application to the Determination of $c t$-DNA
}

\author{
Chunhua Liu ${ }^{1}$, Xiupei Yang ${ }^{1,3}$, Hongyan Yuan ${ }^{2}$, Zaide Zhou ${ }^{1}$ and Dan Xiao ${ }^{1,2^{*}}$ \\ ${ }^{1}$ College of Chemistry, Sichuan University, Chengdu 610064, P. R. China \\ ${ }^{2}$ College of Chemical Engineering, Sichuan University, Chengdu 610064, P. R. China \\ ${ }^{3}$ College of Chemistry and Chemical Engineering, China West Normal University, Nanchong 637002, P. \\ R. China
}
* Author to whom correspondence should be addressed; Fax +86 28 85416029; Tel. +86 2885415029 ; E-mail: xiaodan@scu.edu.cn

Received: 16 March 2007 / Accepted: 29 May 2007 / Published: 31 May 2007

\begin{abstract}
A new method to prepare silver nanoparticles was reported in this paper, which based on aqueous-gaseous phase reaction of silver nitrate solution and ammonia gas. The proposed method is effective, rapid, and convenient. Transmission electron microscope (TEM) and X-ray diffraction (XRD) were used to characterize the structure of the particles, respectively. It was found that the average diameter of the particles was about $10 \mathrm{~nm}$ and the shape was spherical. And the strong fluorescence signal of the silver nanoparticles solution can be quenched after the adding of the calf thymus DNA ( $c t$-DNA) solution. The quenched fluorescence intensity was linear with the concentration of $c t$-DNA in the range of 0.5 to $5.0 \times 10^{4} \mathrm{ng} \mathrm{mL}^{-1}$ with a detection limit of $0.3 \mathrm{ng} \mathrm{mL}^{-1}$.
\end{abstract}

Keywords: silver, nanoparticle, fluorescence, calf thymus DNA ( $c t$-DNA)

\section{Introduction}

In recent years, noble metal nanoparticles have been extensively studied and various approaches have been employed for the preparation of metal nanoparticles [1-6]. Among the noble metal nanoparticles, silver nanoparticles have attracted more attention [7-13] for their advantage on various studies such as photosensitive components [14], catalysts [15-17], and surface-enhanced Raman spectroscopy [18-19]. In this paper, we prepared a kind of silver nanoparticles by the reaction of silver nitrate solution and 
ammonia gas. The products were characterized by powder X-ray diffraction (XRD), transmission electron microscope (TEM) and fluorescence spectrophotometer, respectively. The results showed that the particles were about $10 \mathrm{~nm}$ average diameter and spherical shape. And the strong fluorescence signal would emit when exciting the solution of the nanoparticles by the light with appropriate wavelength. To our best knowledge, quantitative analysis of DNA is very important for medical and biological research [20-23]. A number of methods for the determination of DNA have been established. However, many of them require special reaction conditions. Here, we proposed a new spectrofluorimetric method to determine $c t$-DNA rapidly by fluorescence characteristic of the silver nanoparticles. In our work, we found that strong fluorescence signal generated from the silver nanoparticles solution can be quenched when a $c t$-DNA solution was added in. Based on these observations, a new spectrofluorimetric method was proposed for the determination of $c t$-DNA, with a wide linear range of 0.5 to $5.0 \times 10^{4} \mathrm{ng} \mathrm{mL}^{-1}$ and the detection limit of $0.3 \mathrm{ng} \mathrm{mL}^{-1}$.

\section{Experimental}

Fluorescence spectra were recorded on a F-4500 fluorescence spectrophotometer (Hitachi, Japan). Morphological measurement of the silver nanoparticles was performed by a JEM-100CX transmission electron microscopy (JEOL, Japan). XRD pattern of the silver nanoparticles was obtained by a DX-1000 X-ray powder diffractometer (Dandong, China). UV absorption spectrum was recorded on a UV-1100 spectrophotometer (Shanghai, China).

All reagents used were of analytical grade without any further purification. Calf thymus DNA (ct-DNA) was purchased from Sigma (U.S.). Silver nitrate and ammonia solution were purchased from Chengdu Chemical Reagent Corporation (Chengdu, China). Double distilled water was used throughout the experiment.

The apparatus used in the experiment is shown in Fig. 1. Added $50 \mathrm{~mL}$ silver nitrate solution $(1.0 \times$ $10^{-3} \mathrm{~mol} \mathrm{~L}^{-1}$ ) into a $500 \mathrm{~mL}$ flask (A), which was placed into a constant temperature water bath on a magnetic stirrer. Then $50 \mathrm{~mL}$ ammonia solution $\left(1.0 \mathrm{~mol} \mathrm{~L}^{-1}\right)$ was added into another $500 \mathrm{~mL}$ flask (D). Flasks $\mathrm{A}$ and $\mathrm{D}$ were connected with glass tubes and short pieces of rubber tubes, through which the ammonia gas in flask D volatilized and diffused slowly into the flask A and reacted with the silver nitrate solution. In all stirring procedures of preparing silver nanoparticles, the vessel was exposed to the light of a daylight lamp $(40 \mathrm{~W})$ at a distance of $100 \mathrm{~cm}$. The whole experiment lasted 54 hours. The detailed procedure of preparing silver nanoparticles contained five steps: (1) keep the reaction 11 hours under stirring ( $39^{\circ} \mathrm{C}$ water bath); (2) keep the reaction for 13 hours without stirring and heating; (3) keep the reaction for 10 hours (conditions are same as step 1); (4) repeat the step 2; (5) keep the reaction for 7 hours (conditions are same as step 1). This synthetic method, which proposed in this work, was based on the following reactions:

$$
\begin{aligned}
& \mathrm{Ag}^{+}+\mathrm{OH}^{-} \longrightarrow \mathrm{AgOH} \downarrow \\
& \mathrm{AgOH} \longrightarrow \mathrm{Ag}_{2} \mathrm{O} \\
& \mathrm{Ag}_{2} \mathrm{O} \longrightarrow h v \longrightarrow \mathrm{Ag}
\end{aligned}
$$




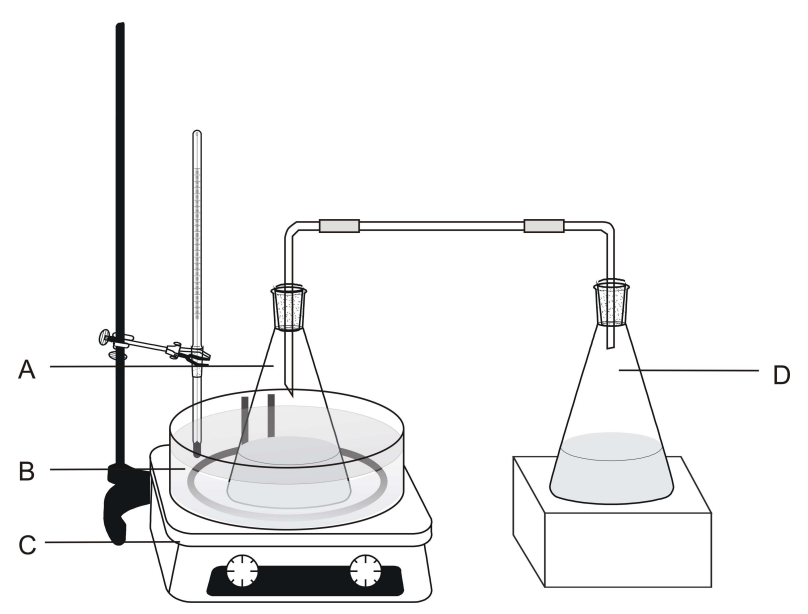

Figure 1. Apparatus for silver nanoparticles synthesis (A. conical flask with $\mathrm{AgNO}_{3}$ solution; B. constant temperature water bath; C. magnetic stirrer; D. conical flask with $\mathrm{NH}_{3} \cdot \mathrm{H}_{2} \mathrm{O}$ ).

\section{Results and Discussion}

\subsection{Optimization of General Procedure}

\subsubsection{Effect of Reactant Concentrations}

In the course of preparing silver nanoparticles, the concentration of silver nitrate solution and ammonia solution played an important role. The different experimental phenomena depended on the preparation conditions were listed in Table 1. Hence, their concentrations should be carefully optimized to ensure preparation success. Under the appropriate condition, the solution of nanoparticles should have strong fluorescence without any precipitation, which can not be observed when the concentrations of silver nitrate and ammonia solutions were too low or too high. Finally, the optimum concentrations of silver nitrate and ammonia solutions were set to $1.0 \times 10^{-3} \mathrm{~mol} \mathrm{~L}^{-1}$ and $1.0 \mathrm{~mol} \mathrm{~L}^{-1}$, respectively. Under the optimum conditions, the produced particles exhibited highest fluorescence intensity and no precipitation occurred as listed in Table 1.

Table 1. Effect of reactant concentrations.

\begin{tabular}{|c|c|c|c|c|}
\hline \multirow{2}{*}{ No. } & \multirow{2}{*}{ Reagents } & \multirow{2}{*}{$\begin{array}{l}\text { Concentration } \\
\left(\mathrm{mol} \mathrm{L}^{-1}\right)\end{array}$} & \multicolumn{2}{|c|}{ Phenomena } \\
\hline & & & Precipitation & Fluorescence \\
\hline 1 & $\begin{array}{l}\mathrm{AgNO}_{3} \\
\mathrm{NH}_{3} \cdot \mathrm{H}_{2} \mathrm{O}\end{array}$ & $\begin{array}{l}1.0 \times 10^{-5} \\
1.0 \times 10^{-5}\end{array}$ & No & No \\
\hline 2 & $\begin{array}{l}\mathrm{AgNO}_{3} \\
\mathrm{NH}_{3} \cdot \mathrm{H}_{2} \mathrm{O}\end{array}$ & $\begin{array}{l}1.0 \times 10^{-5} \\
1.0\end{array}$ & No & No \\
\hline 3 & $\begin{array}{l}\mathrm{AgNO}_{3} \\
\mathrm{NH}_{3} \cdot \mathrm{H}_{2} \mathrm{O}\end{array}$ & $\begin{array}{l}1.0 \times 10^{-4} \\
1.0\end{array}$ & No & No \\
\hline 4 & $\begin{array}{l}\mathrm{AgNO}_{3} \\
\mathrm{NH}_{3} \cdot \mathrm{H}_{2} \mathrm{O}\end{array}$ & $\begin{array}{l}1.0 \times 10^{-3} \\
1.0\end{array}$ & No & Yes \\
\hline 5 & $\begin{array}{l}\mathrm{AgNO}_{3} \\
\mathrm{NH}_{3} \cdot \mathrm{H}_{2} \mathrm{O}\end{array}$ & $\begin{array}{l}1.0 \times 10^{-2} \\
1.0\end{array}$ & Yes & Yes \\
\hline 6 & $\begin{array}{l}\mathrm{AgNO}_{3} \\
\mathrm{NH}_{3} \cdot \mathrm{H}_{2} \mathrm{O}\end{array}$ & $\begin{array}{l}1.0 \\
1.0\end{array}$ & Yes & Yes \\
\hline
\end{tabular}




\subsubsection{Effect of Reaction Time}

Due to a significant effect of the reaction time of the preparation, different reaction time experiments were carried out. From Table 2, it is found that no precipitation and fluorescence were observed when the reaction time was less than 20 hours. The fluorescence began to appear after 20 hours' reaction and increased with the reaction time. However, the fluorescence intensity of nanoparticles was low between 20 and 40 hours. After reacting 60 hours, obvious precipitation occurred. Therefore, the optimum reaction time for the preparation was selected to be 54 hours.

Table 2. Effect of reaction time.

\begin{tabular}{cccc}
\hline \multirow{2}{*}{ No. } & $\begin{array}{c}\text { Reaction time } \\
\text { (hours) }\end{array}$ & Precipitation & Phenomena \\
\cline { 3 - 4 } & 2 & No & Fluorescence \\
\hline 1 & 6 & No & No \\
3 & 10 & No & No \\
4 & 20 & No & No \\
5 & 30 & No & Weak \\
6 & 40 & No & Weak \\
7 & 53 & No & Strong \\
8 & 54 & No & Strong \\
9 & 55 & No & Strong \\
10 & 60 & Yes & Strong \\
\hline
\end{tabular}

\subsection{Fluorescence Spectral Characteristics of the Silver Nanoparticles}

Fig. 2 shows the excitation and emission spectra of the silver nanoparticles. Two excitation peaks appeared at the wavelength of 239 and $314 \mathrm{~nm}$ respectively by emitting at $384 \mathrm{~nm}$. In aqueous medium, the silver nanoparticles had a peak at $384 \mathrm{~nm}$ (curve C) with an excitation at $239 \mathrm{~nm}$. Another emission peak (curve B) of the nanoparticles also occurred at $384 \mathrm{~nm}$ without any shift by changing excitation wavelength from $239 \mathrm{~nm}$ to $314 \mathrm{~nm}$, which indicated that curve B and C were not scattering peaks but fluorescence peaks. The shape and intensity of the two peaks in excitation spectrum A are well in agreement with the curve B and C, respectively. In addition, no significant change was observed in the repetitive experiments within one month, which exhibited excellent stability of the nanoparticles.

Fluorescence tests of regents used in the experiment and by-products were carried out in order to confirm the fluorescence emitted from the nanoparticles. In any spectrogram of Fig. 3, shape and location of the peak excited at $239 \mathrm{~nm}$ (black line) are all different from the peak excited at $314 \mathrm{~nm}$ (red line), which indicates all these peaks are scattering peaks but not fluorescence peaks. We also investigated spectra of possible by-products, $\mathrm{Ag}\left(\mathrm{NH}_{3}\right)_{2} \mathrm{OH}$ and $\mathrm{Ag}_{2} \mathrm{CO}_{3}$, as shown in Fig. 4. For the same reason, the peaks are not fluorescence peaks either. By thorough analysis, we excluded the possibility of fluorescence emitted from regents and possible by-products. 


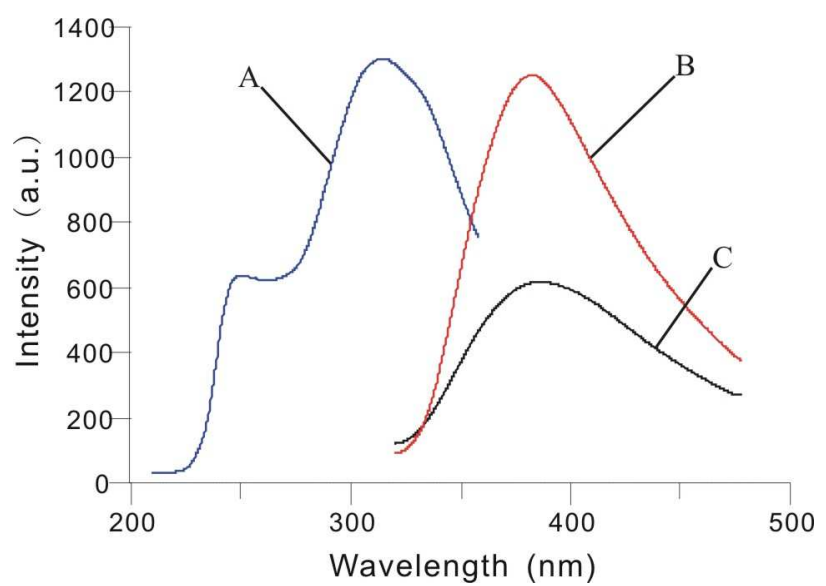

Figure 2. Fluorescence spectra of silver nanoparticles (A. excitation spectra emitted at $384 \mathrm{~nm}$; B. emission spectra excited at $314 \mathrm{~nm}$; C. emission spectra excited at $239 \mathrm{~nm}$ ).
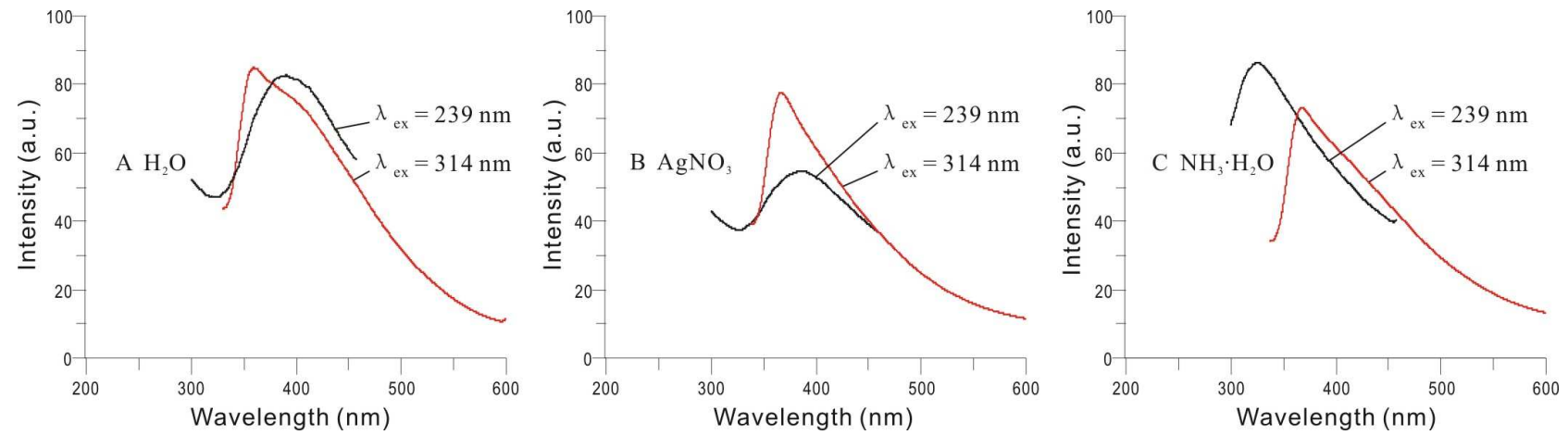

Figure 3. Scattering spectra of reagents (Red lines represent peaks excited at $314 \mathrm{~nm}$, and black lines represent peaks excited at $239 \mathrm{~nm}$. A. $\mathrm{H}_{2} \mathrm{O} ; \mathrm{B} . \mathrm{AgNO}_{3} ;$ C. $\mathrm{NH}_{3} \cdot \mathrm{H}_{2} \mathrm{O}$ ).
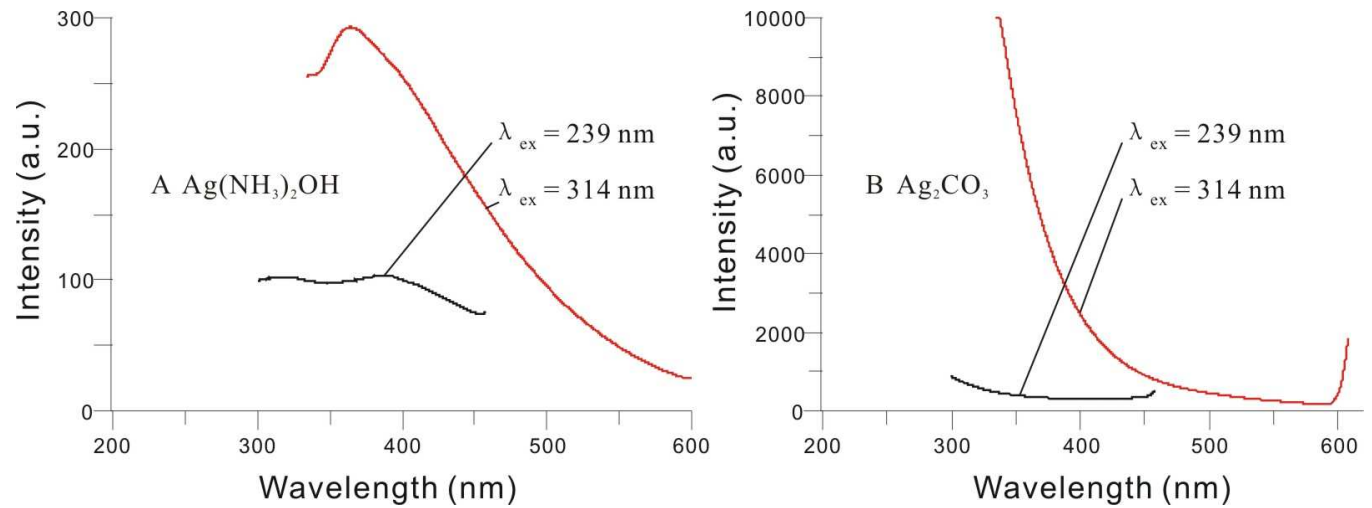

Figure 4. Scattering spectra of $\mathrm{Ag}\left(\mathrm{NH}_{3}\right)_{2} \mathrm{OH}$ and $\mathrm{Ag}_{2} \mathrm{CO}_{3}$ (Red lines represent peaks excited at $314 \mathrm{~nm}$, and black lines represent peaks excited at $239 \mathrm{~nm}$ ). 


\subsection{TEM, ED and XRD Analysis}

The size and morphology of particles were investigated by TEM (transmission electron microscope) and ED (electron diffraction) (Fig. 5). The TEM image indicates that the silver particles are about $10 \mathrm{~nm}$ average diameter and spherical shape. And ED image reveals that the silver nanoparticles are polycrystalline structure.

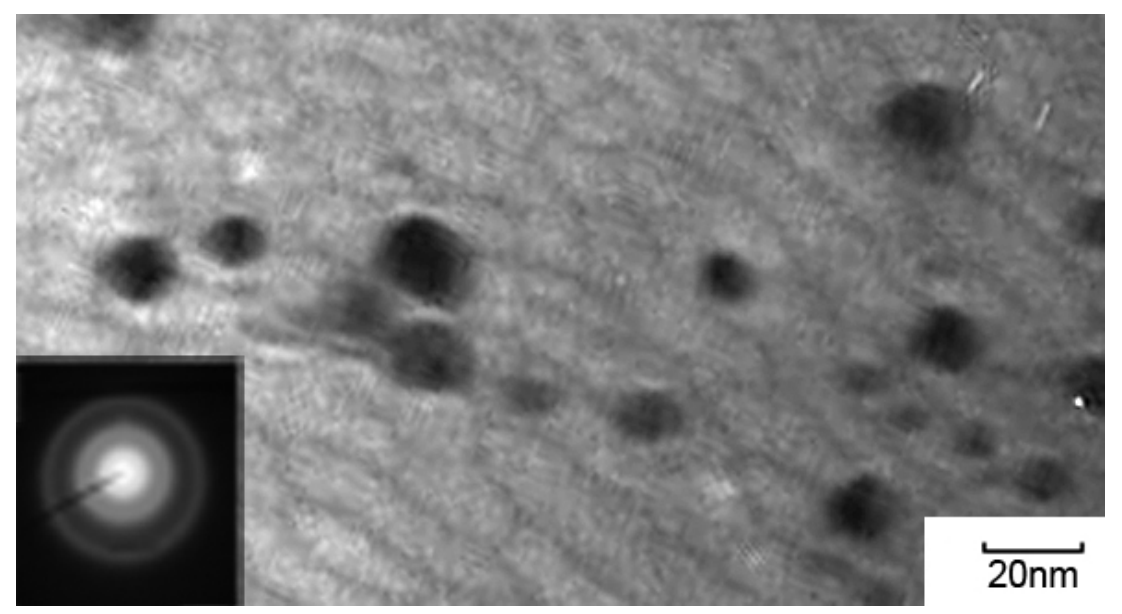

Figure 5. TEM image and the corresponding ED pattern (inset) of silver nanoparticles sample.

The typical powder XRD pattern of the prepared nanoparticles is shown in Fig. 6. The data shows diffraction peaks at $2 \theta=38.2^{\circ}, 44.4^{\circ}, 64.6^{\circ}, 77.5^{\circ}$, and $81.7^{\circ}$, which can be indexed to (111), (200), (220), (311), and (222) planes of pure silver (PDF № 04-0783). It confirmed that the main composition of the nanoparticles was silver. It is also found that there are some little peaks which match with the standard XRD data of $\mathrm{Ag}_{2} \mathrm{CO}_{3}$ (PDF № 26-0339). The silver carbonate formation may be attributed to carbon dioxide in atmosphere. Therefore the product should be preserved in an airproof condition.

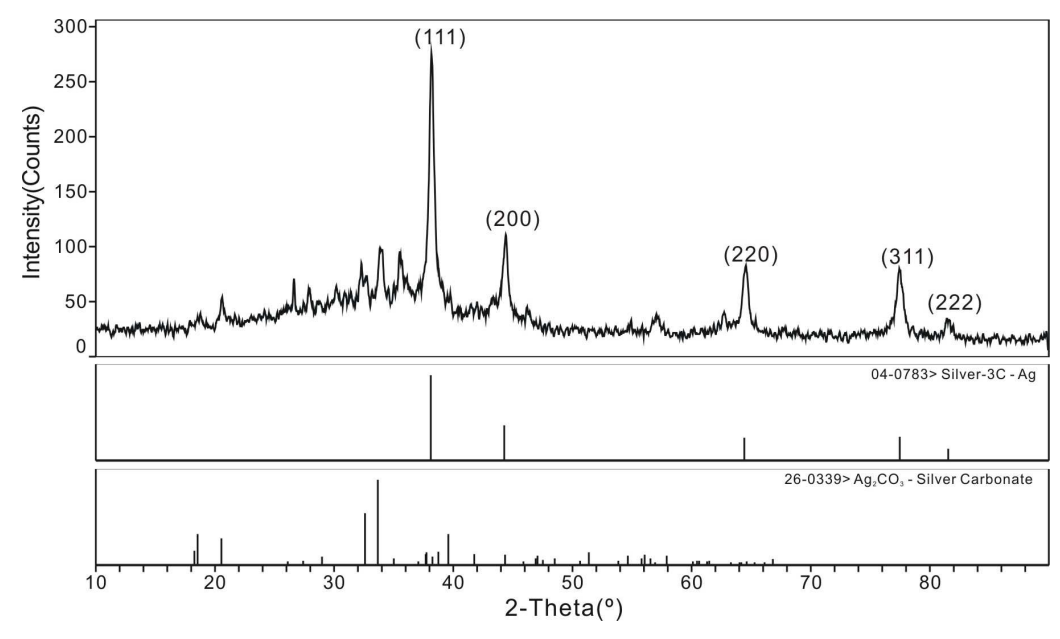

Figure 6. XRD pattern of the silver nanoparticles.

\subsection{Determination of ct-DNA}

As shown in Fig. 7, the effect of the concentration of the silver nanoparticles has also been investigated. At the beginning, with increasing the concentration of the nanoparticles solution, the 
fluorescence intensity of the system increased. However, the intensity increased very slightly after the concentration of the nanoparticles reached $5.0 \times 10^{-4} \mathrm{~mol} \mathrm{~L} \mathrm{~L}^{-1}$, and it dropped slowly when the concentration of nanoparticles reached $8.0 \times 10^{-4} \mathrm{~mol} \mathrm{~L}^{-1}$.

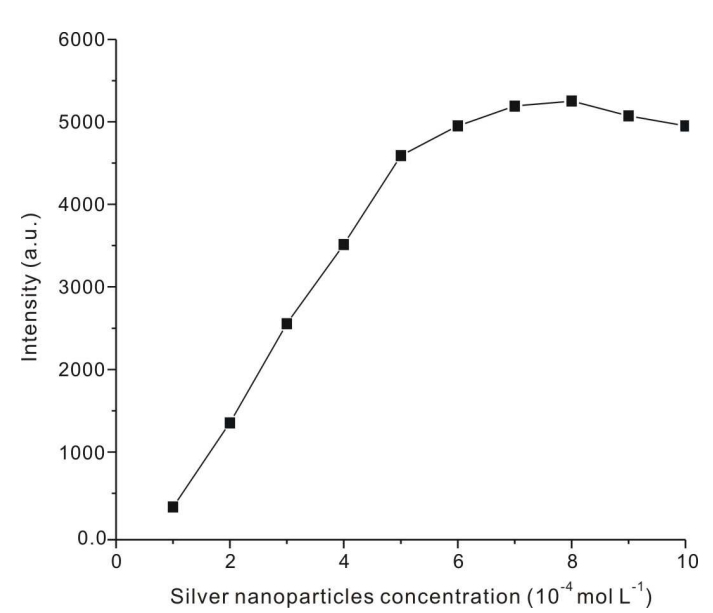

Figure 7. Effect of the concentration of the silver nanoparticles on the relative fluorescence intensity.

When the concentration of the nanoparticles solution was low, the fluorescence intensity decreased which resulted in narrow linear range of detection of $c t$-DNA. However, sensitivity can be improved because of obvious quenching response to adding little $c t$-DNA. Increasing the concentration of the nanoparticles solution to a high value, the enhanced fluorescence led to a wide linear range of detection with sensitivity reducing. At last, in order to acquire both high sensitivity, and wide linear range, the nanoparticles concentration of $5.0 \times 10^{-4} \mathrm{~mol} \mathrm{~L}^{-1}$ is recommended.

Under the optimum conditions defined, spectra of fluorescence quenching of the nanoparticles solutions containing different concentrations of $c t$-DNA are shown in Fig. 8. The strong fluorescence of silver nanoparticles can be quenched in the presence of $c t$-DNA (shown in Fig. 8 b-i). As can be seen in Fig. 9, the linear detection range from 0.5 to $5.0 \times 10^{4} \mathrm{ng} \mathrm{mL}^{-1}$ was achieved. The calibration equation of the best fitted line was $\lg \left[\left(F_{0} / F-1\right) / 0.05\right]=0.2319 \lg \left(\mathrm{C}_{\mathrm{i}} / 0.05\right)-0.2777$, with a correlation coefficient of $0.9953(\mathrm{n}=11, R S D=3.6 \%)$, and a detection limit of $0.3 \mathrm{ng} \mathrm{mL} \mathrm{m}^{-1} . F_{0}$ and $F$ were the fluorescence intensities before and after the addition of $c t$-DNA, respectively, and $\mathrm{C}_{\mathrm{i}}$ was the concentration of $c t$-DNA.

\subsection{Energy Transfer between the Silver Nanoparticles and ct-DNA}

The overlap of the UV absorption spectrum of $c t$-DNA with the fluorescence emission spectrum of the nanoparticles is shown in Fig. 10. It is found that there is an intersection of UV absorption spectrum and fluorescence emission spectrum. Thus the energy transfer from nanoparticles to $c t$-DNA can be happened, which can lead to the quenching of fluorescence. The more clear mechanism of the fluorescence quenching in this experiment still requires further study, which is on progress in our lab. 


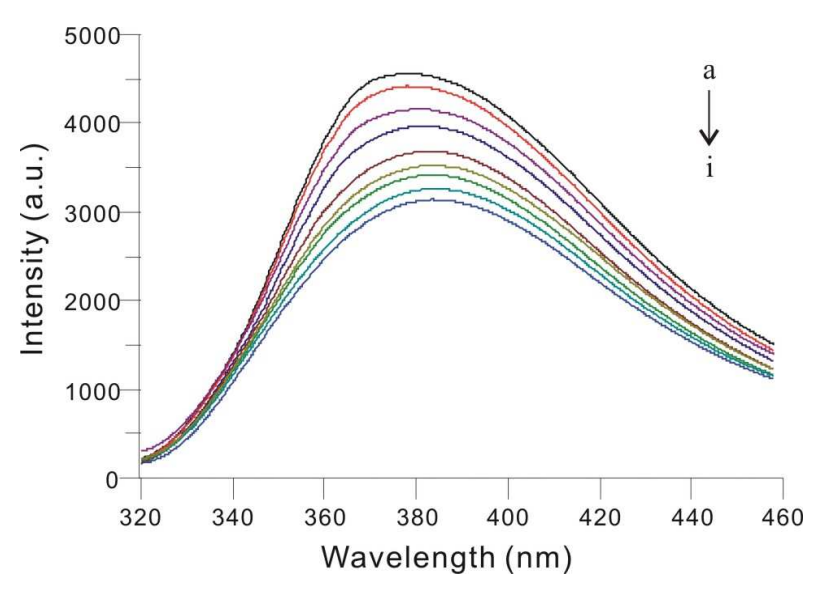

Figure 8. Fluorescence quenching of the nanoparticles solutions containing different concentrations of $c t$-DNA. $\lambda_{\text {em }}=384 \mathrm{~nm}$. The nanoparticles concentration $\left(\mathrm{mol} \mathrm{L}^{-1}\right): 5.0 \times 10^{-4} . c t$-DNA concentration (ng $\left.\mathrm{mL}^{-1}\right)$ a. 0 ; b. 0.5 ; c. 5.0 ; d. $5.0 \times 10$; e. $5.0 \times 10^{2}$; f. $2.5 \times 10^{3}$; g. $5.0 \times 10^{3}$; h. $2.5 \times 10^{4}$; i. $5.0 \times 10^{4}$.

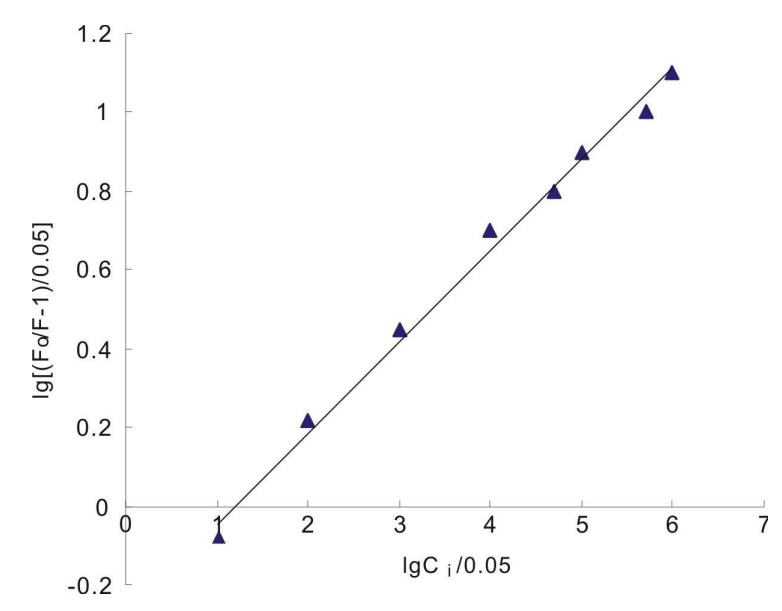

Figure 9. Plot of fluorescence of silver nanoparticles solution quenching by $c t$-DNA (The nanoparticles concentration: $5.0 \times 10^{-4} \mathrm{~mol} \mathrm{~L}^{-1}$ ).

\subsection{Interference of the Coexisting Foreign Substances}

The influences of foreign coexisting substances such as bovine serum albumin, glucose, amino acid and ions were tested. As listed in Table 3, most of the examined coexisting substances had no remarkable interference on the assay. From the results, we can see that interference of bovine serum albumin, amino acid and glucose were very weak. Among the tested ions, $\mathrm{Mg}^{2+}, \mathrm{Zn}^{2+}, \mathrm{Fe}^{3+}, \mathrm{Ca}^{2+}, \mathrm{SO}_{4}{ }^{2-}$, $\mathrm{Cl}^{-}$and $\mathrm{I}^{-}$can be allowed with relatively higher concentrations, but $\mathrm{Cu}^{2+}$ and $\mathrm{PO}_{4}{ }^{3-}$ ions can only be allowed with relatively low concentrations. The allowed concentrations of these interfering substances, however, were still rather higher than that of $c t$-DNA, which indicated that this method had a high selectivity. 


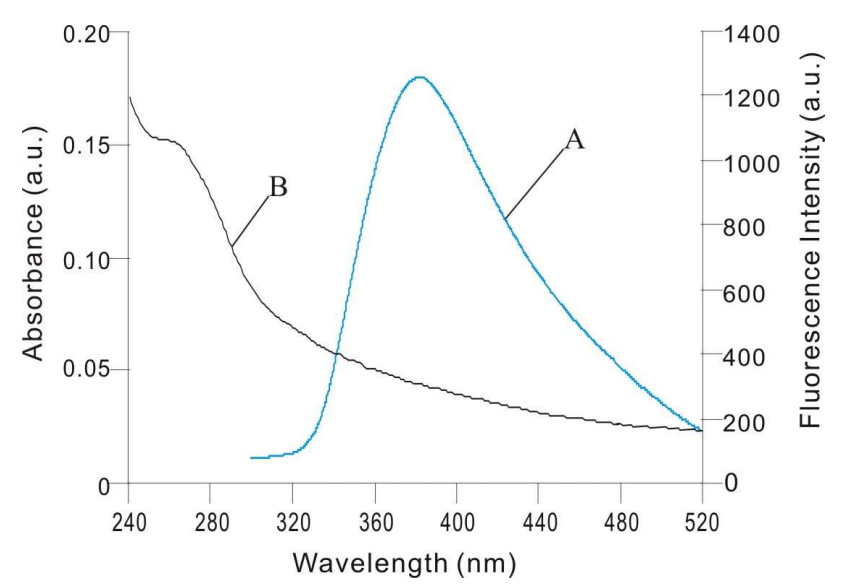

Figure 10. The overlap of the fluorescence spectrum of the silver nanoparticles $\left(\lambda_{\mathrm{em}}=384 \mathrm{~nm}\right)(\mathrm{A})$ with the absorption spectrum of $c t$-DNA (B).

Table 3. Tests for the interference of co-existing substances.

\begin{tabular}{lcc}
\hline \multicolumn{1}{c}{$\begin{array}{c}\text { Co-existing } \\
\text { Substance }\end{array}$} & $\begin{array}{c}\text { Co-existing concentration } \\
\left(\mu \mathrm{g} \mathrm{mL}^{-1}\right)\end{array}$ & $\begin{array}{c}\text { Change in intensity of } \\
\text { fluorescence }(\%)\end{array}$ \\
\hline Bovine Serum Albumin & 5.0 & +2.1 \\
Glucose & 20.0 & +2.0 \\
L-Lysine & 15.0 & -3.3 \\
L-Tyrosine & 10.0 & -4.0 \\
Glutamic acid & 16.0 & +1.5 \\
Glysine & 13.0 & +2.1 \\
L-Histidine & 5.0 & +1.2 \\
$\mathrm{SO}_{4}{ }^{3-}$ & 5.5 & +1.5 \\
$\mathrm{PO}_{4}{ }^{-}$ & 2.0 & +4.0 \\
$\mathrm{Cl}^{-}$ & 6.0 & +3.5 \\
$\mathrm{I}^{-2+}$ & 5.5 & +3.7 \\
$\mathrm{Zn}^{2+}$ & 10.0 & +1.6 \\
$\mathrm{Cu}^{2+}$ & 2.0 & +4.1 \\
$\mathrm{Mg}^{2+}$ & 15.0 & +1.8 \\
$\mathrm{Fe}^{3+}$ & 6.0 & +3.5 \\
$\mathrm{Ca}^{2+}$ & 15.0 & +1.9 \\
\hline
\end{tabular}

Silver nanoparticles, $5.0 \times 10^{-4} \mathrm{~mol} \mathrm{~L}^{-1}$ and $c t$-DNA, $1.0 \mu \mathrm{g} \mathrm{mL}^{-1}$.

\section{Conclusions}

In summary, silver nanoparticles were prepared by the gas-solution reaction of silver nitrate solution and ammonia gas. The silver nanoparticles were about $10 \mathrm{~nm}$ average diameters and spherical shape. The fluorescence of silver nanoparticles was quenched by adding $c t$-DNA, which provided a simple and rapid spectrofluorimetric method for the determination of $c t$-DNA. The linear range of concentration of $c t$-DNA was $0.5-5.0 \times 10^{4} \mathrm{ng} \mathrm{mL}^{-1}$ and the limit of detection was $0.3 \mathrm{ng} \mathrm{mL}^{-1}$. 


\section{Acknowledgements}

This work was supported by the National Natural Science Foundation of China (20575042) and the Science Foundation of the Chinese Education Commission (105141).

\section{References}

1. Yin, B.; Ma, H.; Wang, S.; Chen, S. Electrochemical synthesis of silver nanoparticles under protection of poly(N-vinylpyrrolidone). J. Phys. Chem. B. 2003, 107, 8898-8904.

2. Penner, R.M. Mesoscopic metal particles and wires by electrodeposition. J. Phys. Chem. B. 2002, 106, 3339-3353.

3. Raveendran, P.; Fu, J.; Wallen, S.L. Completely "green" synthesis and stabilization of metal nanoparticles. J. Am. Chem. Soc. 2003, 125, 13940-13941.

4. Lin, X.Z.; Teng, X.; Yang, H. Direct synthesis of narrowly dispersed silver nanoparticles using a single-source precursor. Langmuir 2003, 19, 10081-10085.

5. Carotenuto, G. Synthesis and characterization of poly(N-vinylpyrrolidone) filled by monodispersed silver clusters with controlled size. Appl. Organometal. Chem. 2001, 15, 344-351.

6. Okitsu, K.; Yue, A.; Tanabe, S.; Matsumoto, H. Sonochemical preparation and catalytic behavior of highly dispersed palladium nanoparticles on alumina. Chem. Mater. 2000, 12, 3006-3011.

7. Ghosh, K.; Maiti, S.N. Mechanical properties of silver-powder-filled polypropylene composites. J. Appl. Polym. Sci. 1996, 60, 323-331.

8. Nersisyan, H.H.; Lee, J.H.; Son, H.T.; Won, C.W.; Maeng, D.Y. A new and effective chemical reduction method for preparation of nanosized silver powder and colloid dispersion. Mater. Res. Bull. 2003, 38, 949-956.

9. Rabin, I.; Schulze, W.; Ertl, G.; Felix, C.; Sieber, C.; Harbich, W.; Buttet, J. Absorption and fluorescence spectra of Ar-matrix-isolated $\mathrm{Ag}_{3}$ clusters. J. Chem. Phys. Lett. 2000, 320, 59-64.

10. Geddes, C.D.; Parfenov, A.; Gryczynski, I.; Lakowicz, J.R. Luminescent blinking from silver nanostructures. J. Phys. Chem. B. 2003, 107, 9989-9993.

11. Jiang, Z.; Yuan, W.; Pan, H. Luminescence effect of silver nanoparticle in water phase. Spectrochim. Acta A. 2005, 61, 2488-2494.

12. Maali, A.; Cardinal, T.; Tréguer-Delapierre, M. Intrinsic fluorescence from individual silver nanoparticles. Physica E. 2003, 17, 559-560.

13. Evanoff, D.D.Jr.; Chumanov, G. Size-controlled synthesis of nanoparticles. 1. "silver-only" aqueous suspensions via hydrogen reduction. J. Phys. Chem. B. 2004, 108, 13948-13956.

14. Hailstone, R.K. Computer simulation studies of silver cluster formation on AgBr microcrystals. $J$. Phys. Chem. 1995, 99, 4414-4428.

15. Shiraishi, Y.; Toshima, N. Colloidal silver catalysts for oxidation of ethylene. J. Mol. Catal. A: Chem. 1999, 141, 187-192.

16. Sclafani, A.; Mozzanega, M.; Pichat, P. Effect of silver deposits on the photocatalytic activity of titanium dioxide samples for the dehydrogenation or oxidation of 2-propanol. J. Photochem. Photobiol. A: Chem. 1991, 59, 181-189.

17. Tada, H.; Teranishi, K.; Inubushi, Y.-i.; Ito, S. Ag nanocluster loading effect on $\mathrm{TiO}_{2}$ photocatalytic reduction of bis(2-dipyridyl)disulfide to 2-mercaptopyridine by $\mathrm{H}_{2} \mathrm{O}$. Langmuir 2000, 16, 
3304-3309.

18. Shirtcliffe, N.; Nickel, U.; Schneider, S. Reproducible preparation of silver sols with small particle size using borohydride reduction: for use as nuclei for preparation of larger particles. J. Colloid. Interface. Sci. 1999, 211, 122-129.

19. Bright, R.M.; Musick, M.D.; Natan, M.J. Preparation and characterization of Ag colloid monolayers. Langmuir 1998, 14, 5695-5701.

20. Wang, X.M.; Li, Y.; Gong, S.J.; Fu, D.G. A spectroscopic study on the DNA binding behavior of the anticancer drug dacarbazine. Spectrosc. Lett. 2002, 35, 751-756.

21. Park, S.J.; Taton, T. A.; Mirkin, C. A. Arry-based electrical detection of DNA with nanoparticle. Scienc. 2002, 295, 1503-1506.

22. Li, J.; Xue, M.; Wang, H.; Cheng, L.; Gao, L.; Lu, Z.; Chan, M. Amplifying the electrical hybridization signals of DNA array by multilayer assembly of Au nanoparticles probes. Analyst 2003, 128, 917-923.

23. Zhang, Y.; Kim, H.H.; Heller, A. Enzyme-amplified amperometric detection of 3000 copies of DNA in a $10 \mu \mathrm{L}$ droplet. Anal. Chem. 2003, 75, 3267-3269.

(C) 2007 by MDPI (http://www.mdpi.org). Reproduction is permitted for noncommercial purposes. 